\title{
A Sustainable Improvement of $\omega$-Bromoalkylphosphonates Synthesis to Access Novel KuQuinones
}

\author{
Mattia Forchetta $^{1}$, Valeria Conte ${ }^{1}$ (D) Giulia Fiorani ${ }^{2} \mathbb{D}$, Pierluca Galloni ${ }^{1, *(D)}$ and Federica Sabuzi ${ }^{1, *(D)}$ \\ 1 Department of Chemical Science and Technologies, University of Rome Tor Vergata, Via della Ricerca \\ Scientifica snc, 00133 Rome, Italy; forchetta@scienze.uniroma2.it (M.F.); valeria.conte@uniroma2.it (V.C.) \\ 2 Department of Molecular Sciences and Nanosystems, Ca' Foscari University of Venezia, Via Torino 155, \\ 30172 Venezia, Italy; giulia.fiorani@unive.it \\ * Correspondence: galloni@scienze.uniroma2.it (P.G.); federica.sabuzi@uniroma2.it (F.S.)
}

Citation: Forchetta, M.; Conte, V.; Fiorani, G.; Galloni, P.; Sabuzi, F. A Sustainable Improvement of $\omega$-Bromoalkylphosphonates Synthesis to Access Novel KuQuinones. Organics 2021, 2, 107-117. https://doi.org/10.3390/ org2020010

Academic Editor: Wim Dehaen

Received: 28 April 2021

Accepted: 1 June 2021

Published: 3 June 2021

Publisher's Note: MDPI stays neutral with regard to jurisdictional claims in published maps and institutional affiliations.

Copyright: (c) 2021 by the authors. Licensee MDPI, Basel, Switzerland. This article is an open access article distributed under the terms and conditions of the Creative Commons Attribution (CC BY) license (https:/ / creativecommons.org/licenses/by/ $4.0 /)$.

\begin{abstract}
Owing to the attractiveness of organic phosphonic acids and esters in the pharmacological field and in the functionalization of conductive metal-oxides, the research of effective synthetic protocols is pivotal. Among the others, $\omega$-bromoalkylphosphonates are gaining particular attention because they are useful building blocks for the tailored functionalization of complex organic molecules. Hence, in this work, the optimization of Michaelis-Arbuzov reaction conditions for $\omega$-bromoalkylphosphonates has been performed, to improve process sustainability while maintaining good yields. Synthesized $\omega$-bromoalkylphosphonates have been successfully adopted for the synthesis of new KuQuinone phosphonate esters and, by hydrolysis, phosphonic acid KuQuinone derivatives have been obtained for the first time. Considering the high affinity with metal-oxides, KuQuinones bearing phosphonic acid terminal groups are promising candidates for biomedical and photo(electro)chemical applications.
\end{abstract}

Keywords: $\omega$-bromoalkylphosphonates; KuQuinones; phosphonate esters; diethyl phosphonates; organic phosphonic acids; Arbuzov reaction; triethyl phosphite; phosphonate ester hydrolysis; dibromoalkane; anchoring group

\section{Introduction}

Phosphonic acid (PA) functionalization of organic compounds is of great interest in various scientific areas. Several pharmacologically active compounds bearing a PA group (or the corresponding phosphonate salt) have been developed over the years [1,2] Organic phosphonic acid derivatives, such as phosphonoformic or phosphonoacetic acids and many others, resulted in promising antiviral drugs $[3,4]$ and, recently, the aromatic analogue, phosphonobenzoic acid, has been object of a theoretical study on Covid-SARS [5]. Additionally, fosmidomycin and its $\alpha$-substituted derivatives are effective anti-malarian drugs [6], while fosfomycin is a widely used antibiotic [7]. Notably, the presence of a phosphonic acid group significantly improves organic molecules hydrophilicity, which is an essential feature for biomedical application [8].

PAs are also optimal hydrogen bond donors and acceptors; therefore, they are employed in supramolecular chemistry, for metal-organic frameworks and organic proton conductors [9-12]. The dianionic nature of the deprotonated form of PA is pivotal for covalently binding different metal oxides, in mono-, bi- or tri-dentate architectures [13]. In fact, PA is a robust anchoring group, widely adopted for organic molecules immobilization on metal oxide surfaces and nanoparticles [14-21]. Therefore, phosphonic acid functionalization of organic and metallorganic photosensitizers is a proficient tool to decorate metal oxides for their application in dye-sensitized solar cells, photoelectrochemical devices [22,23] as well as in organocatalysis [24-27].

With respect to photoelectrochemical applications, we have been recently involved in the use of metal-free quinoid compounds, i.e., KuQuinones (KuQs), as photosentisiz- 
ers on indium-tin oxide (ITO) [28], $\mathrm{NiO}$ [29] and on $\mathrm{SnO}_{2}$ [30], due to their favorable electrochemical and photophysical properties [31]. In this respect, terminal hydroxy or carboxylic acid functionalities were introduced in KuQuinone structure to ensure a stable and effective metal oxide binding. Additionally, differently functionalized KuQs were tested as anti-proliferative agents against ovarian and colon cancer cells, with promising results [32,33].

In an attempt to extend KuQuinones application in the photo(electro)chemical and biomedical fields, the synthesis of new KuQuinone phosphonic acid derivatives was investigated. As a matter of fact, compared to carboxylates, PAs are better anchoring groups in terms of stability [34,35], bond strength [36-38] and monolayer deposition reproducibility [39]. Additionally, PA functionalization is expected to enhance KuQ pharmacological applications. In this framework, according to the previously reported synthetic procedure, to obtain new KuQuinone phosphonic acid derivatives, the synthesis of suitable $\omega$-bromoalkylphosphonate esters was required (Scheme 1) [32].

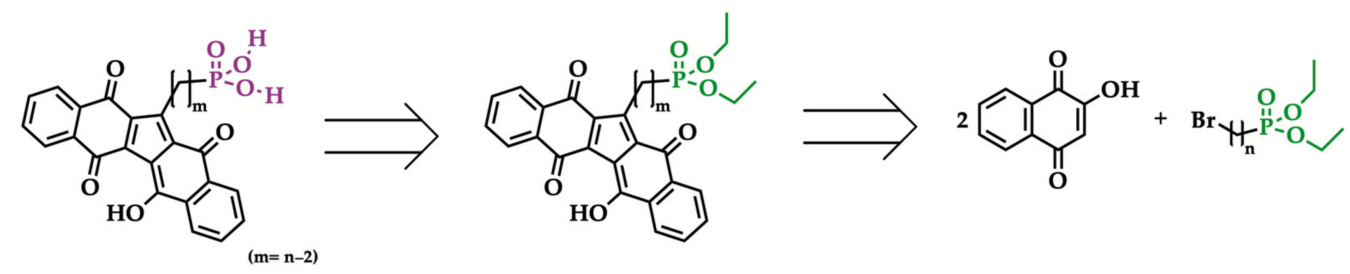

Scheme 1. Retrosynthetic analysis to obtain new KuQuinone phosphonic acid derivatives [32].

The first synthesis of alkylphosphonate esters has been proposed more than 100 years ago by Michaelis and Arbuzov [40,41]. Optimized reaction conditions required the use of an alkyl bromide with an excess of triethyl phosphite. Reactions proceeded solventless, at high temperatures, with good yields. Later, the synthesis of $\omega$-bromoalkylphosphonates was also experienced with Arbuzov's reaction [41]. Here, a dibromoalkane was used as the substrate. Nevertheless, such reactions lacked selectivity, because the di-substitution process occurred; therefore, a large excess of the dibromoalkane was required [42-46]. In that respect, although the authors claimed that the unreacted substrate can be recovered by fractional distillation and reused, it is worth mentioning that such a recovery procedure is actually problematic and time-consuming, because of the very similar boiling points of the reaction components. Therefore, in this paper, optimization of Michaelis-Arbuzov reaction conditions for the synthesis of $\omega$-bromoalkylphosphonate esters is investigated, using an equimolar amount of reagents, to enhance process sustainability. The synthesized compounds are adopted for the synthesis of new KuQuinone derivatives.

\section{Materials and Methods}

All commercial reagents and solvents were purchased from Sigma Aldrich/MerckLife Science (KGaA, Darmstadt, Germany), with the highest degree of purity, and they were used without any further purification. UV-vis absorption spectra were recorded with a UVVis 2450 (Shimadzu, Kyoto, Japan) spectrophotometer. ATR-IR spectra were recorded with a FT-IR Nicolet iS50 (Thermo Scientific, Madison, WI, USA) spectrometer. Melting points were measured using a Büchi 512 melting point apparatus (Büchi, Flawil, $\mathrm{CH}$ ) and all values were uncorrected. GC-MS analyses have been performed with a (Shimadzu, Kyoto, Japan) GCMS QP2010 Ultra system. ${ }^{1} \mathrm{H}-\mathrm{NMR}$ and ${ }^{31} \mathrm{P}-\mathrm{NMR}$ spectra were recorded with a Bruker AM400 NMR spectrometer (Bruker, Billerica, MA, USA) operating frequency of $400 \mathrm{MHz}$. Reactions with MW have been performed with a Microwave Accelerated Reaction System, Model MARS Xpress 5-CEM (CEM Corporation, Matthews, NC, USA). High-resolution mass spectra (HRMS) were recorded with a Bruker Compact QTOF instrument (Bruker, Billerica, MA, USA). Spectra have been acquired in positive or negative ion mode, with a mass resolution of $R=30,000$. 


\subsection{Optimized Procedure for the Synthesis of Diethyl $\omega$-Bromoalkylphosphonate}

Glassware was flamed under nitrogen flow. The reaction flask was connected to a distillation apparatus, in order to distill the bromoethane produced during the process. A total of $75 \mathrm{mmol}$ of $\alpha, \omega$-dibromoalkane were pre-heated at $140{ }^{\circ} \mathrm{C} ; 75 \mathrm{mmol}$ of triethyl phosphite were then added dropwise, within $2 \mathrm{~h}$. The mixture was stirred for an additional hour and monitored by GC-MS. Pure diethyl $\omega$-bromoalkylphosphonate was isolated by vacuum fractional distillation, with satisfactory yield. Product characterization has been performed with GC-MS, ${ }^{1} \mathrm{H}$ and ${ }^{31} \mathrm{P}$ NMR in $\mathrm{CDCl}_{3}$ (see Supplementary Materials). Reactions have been performed in duplicate and good reproducibility was observed.

Diethyl 6-bromohexylphosphonate (1). Colorless oil (9.19 g, $30.5 \mathrm{mmol}, 40 \%$ yield). MS (EI, $70 \mathrm{eV}): m / z=221[\mathrm{M}-\mathrm{Br}]^{+} ; m / z=152\left[{ }^{\circ} \mathrm{CH}_{2} \mathrm{P}(=\mathrm{OH})\left(\mathrm{OCH}_{2} \mathrm{CH}_{3}\right)_{2}\right]^{+} ; m / z=125[152-$ $\left.\mathrm{C}_{2} \mathrm{H}_{3}\right]^{+}[47,48] .{ }^{1} \mathrm{H}$ NMR $\left(\mathrm{CDCl}_{3}, 400 \mathrm{MHz}\right): \delta 1.322(\mathrm{t}, J=7.09 \mathrm{~Hz}, 6 \mathrm{H}), \delta 1.366-1.509(\mathrm{~m}$, $4 \mathrm{H}), \delta 1.562-1.667(\mathrm{~m}, 4 \mathrm{H}), \delta 1.819-1.908(\mathrm{~m}, 2 \mathrm{H}), \delta 3.402(\mathrm{t}, J=6.74 \mathrm{~Hz}, 2 \mathrm{H}), \delta 4.030-4.160$

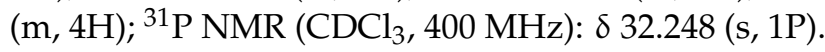

Diethyl 5-bromopentylphosphonate (2). Colorless oil (8.17 g, $29.5 \mathrm{mmol}, 40 \%$ yield). MS (EI, $70 \mathrm{eV}): m / z=207[\mathrm{M}-\mathrm{Br}]^{+} ; m / z=152\left[{ }^{\circ} \mathrm{CH}_{2} \mathrm{P}(=\mathrm{OH})\left(\mathrm{OCH}_{2} \mathrm{CH}_{3}\right)_{2}\right]^{+} ; m / z=125[152-$ $\left.\mathrm{C}_{2} \mathrm{H}_{3}\right]^{+}[47,48] .{ }^{1} \mathrm{H}$ NMR $\left(\mathrm{CDCl}_{3}, 400 \mathrm{MHz}\right): \delta 1.322(\mathrm{t}, J=7.06,6 \mathrm{H}), \delta 1.475-1.739(\mathrm{~m}, 6 \mathrm{H})$, $\delta 1.826-1.920(\mathrm{~m}, 2 \mathrm{H}), \delta 3.404(\mathrm{t}, J=6.72 \mathrm{~Hz}, 2 \mathrm{H}), \delta 4.013-4.166(\mathrm{~m}, 4 \mathrm{H}) ;{ }^{31} \mathrm{P} \mathrm{NMR}\left(\mathrm{CDCl}_{3}\right.$, $400 \mathrm{MHz}): \delta 31.926(\mathrm{~s}, 1 \mathrm{P})$.

Diethyl 4-bromobutylphosphonate (3). Colorless oil (4.24 g, $15.5 \mathrm{mmol}, 20 \%$ yield). MS (EI, $70 \mathrm{eV}): m / z=193[\mathrm{M}-\mathrm{Br}]^{+} ; m / z=165\left[193-\mathrm{C}_{2} \mathrm{H}_{4}\right]^{+} ; m / z=137\left[165-\mathrm{C}_{2} \mathrm{H}_{4}\right]^{+} .{ }^{1} \mathrm{H} \mathrm{NMR}$ $\left(\mathrm{CDCl}_{3}, 400 \mathrm{MHz}\right): \delta 1.326(\mathrm{t}, J=7.05,6 \mathrm{H}), \delta 1.730-1.821(\mathrm{~m}, 4 \mathrm{H}), \delta 1.918-2.002(\mathrm{~m}, 2 \mathrm{H})$, $\delta 3.409(\mathrm{t}, J=6.56 \mathrm{~Hz}, 2 \mathrm{H}), \delta 4.042-4.156(\mathrm{~m}, 4 \mathrm{H}) . ;{ }^{31} \mathrm{P} \mathrm{NMR}\left(\mathrm{CDCl}_{3}, 400 \mathrm{MHz}\right): \delta 31.400$ $(\mathrm{s}, 1 \mathrm{P})$.

\subsection{General Procedure for the Synthesis of 1-[n-(Diethyl phosphonyl) alkyl]KuQuinone}

$5.75 \mathrm{mmol}$ of 2-hydroxy-1,4-naphthoquinone, $12 \mathrm{mmol}$ of $\omega$-bromoalkylphosphonate, $8 \mathrm{mmol}$ of $\mathrm{Cs}_{2} \mathrm{CO}_{3}, 0.33 \mathrm{mmol}$ of sublimated ferrocene and $22 \mathrm{~mL}$ of dimethyl sulfoxide were mixed at $114{ }^{\circ} \mathrm{C}$, for $41 \mathrm{~h}$. The crude was then diluted with $100 \mathrm{~mL}$ of dichloromethane, filtered and extracted with $\mathrm{NaCl}$ saturated aqueous solution. The organic phase was subsequently dried over $\mathrm{Na}_{2} \mathrm{SO}_{4}$, filtered and concentrated. Purification was carried out by chromatography column $\left(\mathrm{SiO}_{2} / \mathrm{CHCl}_{3}\right)$. The sample was dried and then further purified by precipitation with chloroform/hexane. The product was characterized by UV-vis and IR spectroscopy, HRMS, ${ }^{1} \mathrm{H},{ }^{13} \mathrm{C}$ and ${ }^{31} \mathrm{P} \mathrm{NMR}$ in $\mathrm{CDCl}_{3}$ (see Supplementary Materials).

1-[4-(Diethyl phosphonyl)butyl]KuQuinone (4). Purple powder (103.94 mg, $0.2 \mathrm{mmol}, 7 \%$ yield) $\mathrm{mp} 185-188^{\circ} \mathrm{C} .{ }^{1} \mathrm{H}$ NMR $\left(\mathrm{CDCl}_{3}, 400 \mathrm{MHz}\right): \delta 1.303(\mathrm{t}, J=7.08 \mathrm{~Hz}, 6 \mathrm{H}), \delta 1.593-1.802$ $(\mathrm{m}, 6 \mathrm{H}), \delta 3.350-3.423(\mathrm{t}, J=7.28 \mathrm{~Hz}, 2 \mathrm{H}), \delta 4.026-4.147(\mathrm{~m}, 4 \mathrm{H}), \delta 7.622-7.729(\mathrm{~m}, 4 \mathrm{H})$, $\delta 8.102-8.199(\mathrm{~m}, 4 \mathrm{H}), \delta 18.072(\mathrm{~s}, 1 \mathrm{H}) .{ }^{13} \mathrm{C} \mathrm{NMR}\left(\mathrm{CDCl}_{3}, 400 \mathrm{MHz}\right): \delta 181.052$ and 177.973 $(\mathrm{C}=\mathrm{O}) ; \delta 136.089,135.692,135.127,133.150,131.905,127,798,127.341,125.753$ (aromatic carbons); $\delta 59.894,27.354,23.433,22.360,20.465,16.428$ (aliphatic carbons). ${ }^{31} \mathrm{P}$ NMR $\left(\mathrm{CDCl}_{3}, 400 \mathrm{MHz}\right): \delta 32.686$ (s, 1P). UV - vis in $\mathrm{CHCl}_{3}\left[\lambda_{\max }, \mathrm{nm}\left(\varepsilon, \mathrm{M}^{-1} \mathrm{~cm}^{-1}\right)\right]: 569(14,919)$; $532(12,240)$. HRMS: $m / z$ [M + Na] ${ }^{+}$calculated for $\mathrm{C}_{29} \mathrm{H}_{27} \mathrm{NaO}_{7} \mathrm{P} 541.1387$; found 541.1394.

1-[3-(Diethyl phosphonyl)propyl]KuQuinone (5). Purple powder (145.21 mg, $0.3 \mathrm{mmol}, 10 \%$ yield) mp 204-206 ${ }^{\circ} \mathrm{C} .{ }^{1} \mathrm{H}$ NMR $\left(\mathrm{CDCl}_{3}, 400 \mathrm{MHz}\right): \delta 1.281(\mathrm{t}, J=7.08 \mathrm{~Hz}, 6 \mathrm{H}), \delta 1.862-2.053$ $(\mathrm{m}, 4 \mathrm{H}), \delta 3.486(\mathrm{t}, J=7.09,2 \mathrm{H}), \delta 3.991-4.152(\mathrm{~m}, 4 \mathrm{H}), \delta 7.628-7.780(\mathrm{~m}, 4 \mathrm{H}), \delta 8.120-8.238$ $(\mathrm{m}, 4 \mathrm{H}), \delta 18.150(\mathrm{~s}, 1 \mathrm{H}) .{ }^{13} \mathrm{C} \mathrm{NMR}\left(\mathrm{CDCl}_{3}, 400 \mathrm{MHz}\right): \delta 180.876$ and $178.090(\mathrm{C}=\mathrm{O})$; $\delta 135.664,135.133,133.125,132.638,131.836,127,827,127.344,125.515$ (aromatic carbons); $\delta$ 61.437, 26.312, 24.920, 22.263, 16.524 (aliphatic carbons). ${ }^{31} \mathrm{P} \mathrm{NMR}\left(\mathrm{CDCl}_{3}, 400 \mathrm{MHz}\right)$ : $\delta 32.337$ (s, 1P). UV-vis in $\mathrm{CHCl}_{3}\left[\lambda_{\max }, \mathrm{nm}\left(\varepsilon, \mathrm{M}^{-1} \mathrm{~cm}^{-1}\right)\right]$ : $567(14,851) ; 529(11,351)$. HRMS: $m / z[\mathrm{M}+\mathrm{Na}]^{+}$calculated for $\mathrm{C}_{28} \mathrm{H}_{25} \mathrm{NaO}_{7} \mathrm{P}$ 527.1230; found 527.1234. 
1-[2-(Diethyl phosphonyl)ethyl]KuQuinone (6). Purple powder (152.60 mg, $0.3 \mathrm{mmol}, 11 \%$ yield) $\mathrm{mp} 220-222{ }^{\circ} \mathrm{C} .{ }^{1} \mathrm{H}$ NMR $\left(\mathrm{CDCl}_{3}, 400 \mathrm{MHz}\right): \delta 1.423(\mathrm{t}, J=7.00 \mathrm{~Hz}, 6 \mathrm{H}), \delta 2.102-2.224$ $(\mathrm{m}, 2 \mathrm{H}), \delta 3.602-3.702(\mathrm{~m}, 2 \mathrm{H}), \delta 4.157-4.320(\mathrm{~m}, 4 \mathrm{H}), \delta 7.645-7.764(\mathrm{~m}, 4 \mathrm{H}), \delta 8.163-8.228$ $(\mathrm{m}, 4 \mathrm{H}), \delta 18.147(\mathrm{~s}, 1 \mathrm{H}) .{ }^{13} \mathrm{C} \mathrm{NMR}\left(\mathrm{CDCl}_{3}, 400 \mathrm{MHz}\right): \delta 30.835(\mathrm{~s}, 1 \mathrm{P}) . \delta 180.888$ and $178.309(\mathrm{C}=\mathrm{O}) ; \delta 135.613,135.183,133.164,132.404,131.861,127,925,127.363,125.434$ (aromatic carbons); $\delta 61.827,24.772,20.637,16.621$ (aliphatic carbons). ${ }^{31} \mathrm{P} \mathrm{NMR}\left(\mathrm{CDCl}_{3}\right.$, $400 \mathrm{MHz})$. UV-vis in $\mathrm{CHCl}_{3}\left[\lambda_{\max }, \mathrm{nm}\left(\varepsilon, \mathrm{M}^{-1} \mathrm{~cm}^{-1}\right)\right]: 563(14,544) ; 526(11,367)$. HRMS: $m / z[\mathrm{M}+\mathrm{Na}]^{+}$calculated for $\mathrm{C}_{27} \mathrm{H}_{23} \mathrm{NaO}_{7} \mathrm{P}$ 513.1074; found 513.1069.

\subsection{Hydrolysis of Diethyl Phosphonate KuQuinone Derivatives}

Glassware was flamed under nitrogen flow before use. A total of $0.1 \mathrm{mmol}$ of diethyl phosphonate KuQuinone and $5 \mathrm{mmol}$ of $\mathrm{NaI}$ were mixed in $16 \mathrm{~mL}$ of dry acetonitrile: chloroform solution $(1: 1 \mathrm{v} / \mathrm{v})$ until a deep purple solution was observed. Subsequently, $5 \mathrm{mmol}$ of bromotrimethylsilane were added and the mixture was stirred for $4 \mathrm{~h}$, at $40{ }^{\circ} \mathrm{C}$, under an inert atmosphere. The crude was then diluted with $15 \mathrm{~mL}$ of chloroform, filtered and concentrated under vacuum, obtaining the bis-(trimethylsilyl)phosphonate intermediate, as a brownish oil. The silyl ester was converted to the corresponding acid by hydrolysis with $30 \mathrm{~mL}$ of methanol, under magnetic stirring, within an hour. Phosphonic acid, in form of a purple precipitate, was isolated by vacuum filtration, washed with diethyl ether and characterized by ${ }^{1} \mathrm{H}$ and ${ }^{31} \mathrm{P}$ NMR in DMSO- $d_{6}$, IR and HRMS (see Supplementary Materials).

1-[4-(Dihydroxyphosphonyl)butyl]KuQuinone (7). Purple powder (44.83 mg, $0.097 \mathrm{mmol}, 97 \%$ yield) $\mathrm{mp}>250{ }^{\circ} \mathrm{C} .{ }^{1} \mathrm{H}$ NMR (DMSO- $\left.d_{6}, 400 \mathrm{MHz}\right): \delta 1.493-1.617(\mathrm{~m}, 6 \mathrm{H}), \delta 7.529-7.697$ $(\mathrm{m}, 4 \mathrm{H}), \delta 7.891-8.035$ (m, 4H). ${ }^{31} \mathrm{P}$ NMR (DMSO-d, $\left.400 \mathrm{MHz}\right): \delta 26.653$ (s, 1P). HRMS: $m / z$ $[\mathrm{M}-\mathrm{H}]^{-}$calculated for $\mathrm{C}_{25} \mathrm{H}_{18} \mathrm{O}_{7} \mathrm{P}$ 461.0796; found 461.0786.

1-[3-(Dihydroxyphosphonyl)propyl]KuQuinone (8). Purple powder (42.56 mg, $0.095 \mathrm{mmol}, 95 \%$ yield) $\mathrm{mp}>250{ }^{\circ} \mathrm{C} .{ }^{1} \mathrm{H}$ NMR (DMSO-d ${ }_{6}, 400 \mathrm{MHz}$ ): $\delta 1.493-1.617(\mathrm{~m}, 6 \mathrm{H}), \delta 7.529-7.697$ $(\mathrm{m}, 4 \mathrm{H}), \delta 7.891-8.035$ (m, 4H). ${ }^{31} \mathrm{P}$ NMR (DMSO- $\left.d_{6}, 400 \mathrm{MHz}\right): \delta 26.534$ (s, 1P). HRMS: $m / z$ $[\mathrm{M}-\mathrm{H}]^{-}$calculated for $\mathrm{C}_{24} \mathrm{H}_{16} \mathrm{O}_{7} \mathrm{P} 447.0639$; found 447.0625.

1-[2-(Dihydroxyphosphonyl)ethyl]KuQuinone (9). Purple powder (43.38 mg, $0.1 \mathrm{mmol}, 100 \%$ yield) $\mathrm{mp}>250{ }^{\circ} \mathrm{C} .{ }^{1} \mathrm{H}$ NMR (DMSO-d $\left.6,400 \mathrm{MHz}\right): \delta 1.692-1.847(\mathrm{~m}, 2 \mathrm{H}), \delta 7.509-7.677$ $(\mathrm{m}, 4 \mathrm{H}), \delta 7.921-8.045$ (m, 4H). ${ }^{31} \mathrm{P}$ NMR (DMSO-d 6 , $\left.400 \mathrm{MHz}\right): \delta 26.483$ (s, 1P). HRMS: $m / z$ $[\mathrm{M}-\mathrm{H}]^{-}$calculated for $\mathrm{C}_{23} \mathrm{H}_{14} \mathrm{O}_{7} \mathrm{P} 433.0483$; found 433.0478 .

\section{Results and Discussion}

Synthesis of diethyl $\omega$-bromoalkylphosphonates has been explored, in order to optimize Arbuzov reaction conditions [41]. Previous works on phosphonate esters monofunctionalization of dibromoalkanes highlighted that a high excess (from 3 to 20 equivalents) of substrate was required to avoid di-substitution reaction [42-46]. In this study, 1,4-dibromobutane, 1,5-dibromopentane and 1,6-dibromohexane have been selected as substrates to perform Arbuzov synthesis. The reactions have been carried out solventless, at $140{ }^{\circ} \mathrm{C}$, using equimolar amount of triethyl phosphite with respect to the substrate, in order to improve process sustainability, thus reducing waste (Scheme 2). The reactions were monitored by GC-MS. Products isolation has been performed by fractional distillation under vacuum. The results are reported in Table 1.

Solvent-free Arbuzov reaction between triethyl phosphite and 1,4-dibromobutane, in equimolar amount, was performed following a previously reported procedure (Table 1 , Entry 1) [49,50]. However, in the adopted conditions, GC-MS analysis revealed that diethyl ethylphosphonate was the main product. As a matter of fact, during the Arbuzov reaction, bromoethane is formed as a byproduct (Scheme 3a) and it readily reacted with triethyl phosphite, leading to diethyl ethylphosphonate, in a high amount (Scheme 3b). Only traces of diethyl 4-bromobutylphosphonate (3) and the di-substituted product were detected. 


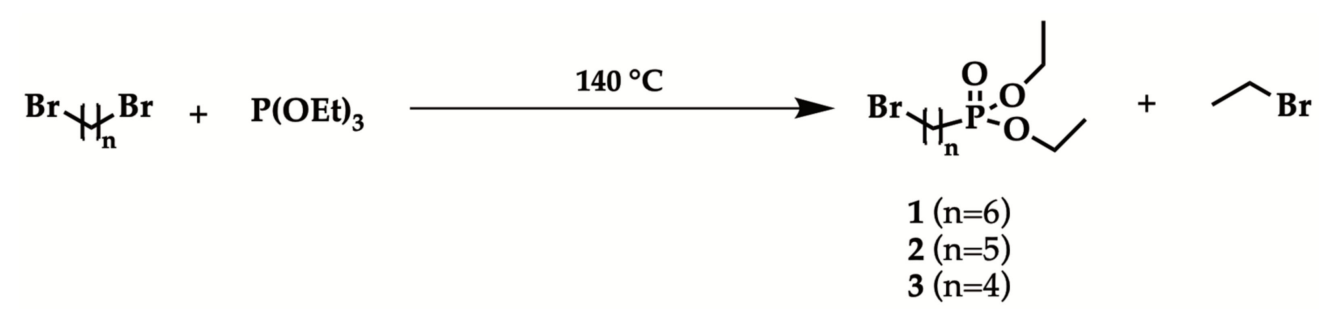

Scheme 2. Diethyl $\omega$-bromoalkylphosphonates synthesis.

Table 1. Optimization of reaction conditions for the synthesis of diethyl $\omega$-bromoalkylphosphonate. Conditions: $\alpha, \omega$-dibromoalkane $(75 \mathrm{mmol})$ : triethyl phosphite $(75 \mathrm{mmol}) ; \mathrm{T}=140{ }^{\circ} \mathrm{C}$.

\begin{tabular}{cccc}
\hline Entry & $\mathbf{B r}\left(\mathbf{C H}_{\mathbf{2}}\right)_{\mathbf{n}} \mathbf{B r}$ & Reaction Time & Isolated Yield (\%) \\
\hline 1 & $\mathrm{n}=4$ & $12 \mathrm{~h}$ & - \\
$2^{\mathrm{a}}$ & $\mathrm{n}=4$ & $12 \mathrm{~h}$ & - \\
$3^{\mathrm{b}}$ & $\mathrm{n}=4$ & $5 \mathrm{~min}$ & - \\
$4^{\mathrm{a}, \mathrm{c}}$ & $\mathrm{n}=6$ & $90 \mathrm{~min}$ & 40 \\
$5^{\mathrm{a}, \mathrm{d}}$ & $\mathrm{n}=6$ & $3 \mathrm{~h}$ & 40 \\
$6^{\mathrm{a}, \mathrm{d}}$ & $\mathrm{n}=5$ & $3 \mathrm{~h}$ & $20^{\mathrm{e}}$ \\
$7^{\mathrm{a}, \mathrm{d}}$ & $\mathrm{n}=4$ & $3 \mathrm{~h}$ & \\
\hline
\end{tabular}

$\bar{a}$ Bromoethane distilled during the reaction. ${ }^{\mathrm{b}}$ microwave irradiation at $150 \mathrm{~W} .{ }^{\mathrm{c}}$ triethyl phosphite dropwise addition within 30 min. ${ }^{d}$ triethyl phosphite dropwise addition within $2 \mathrm{~h} .{ }^{e}$ isolated by column chromatography (ethyl acetate $/ \mathrm{Al}_{2} \mathrm{O}_{3}$ ).

(a)<smiles>CCOP(OCC)O[P+](OCC)OCC</smiles>

(b)

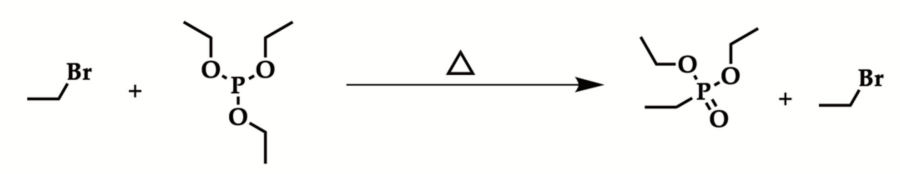

(c)<smiles>CCOP(=O)(CCCCBr)OCC</smiles>

(3)<smiles>CCOP(OCC)OCC</smiles>

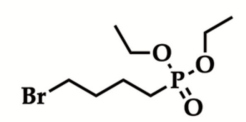

(3)

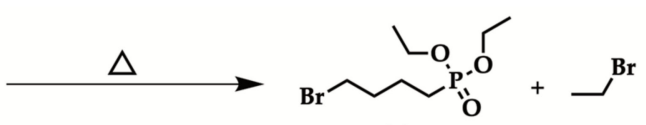

(3)
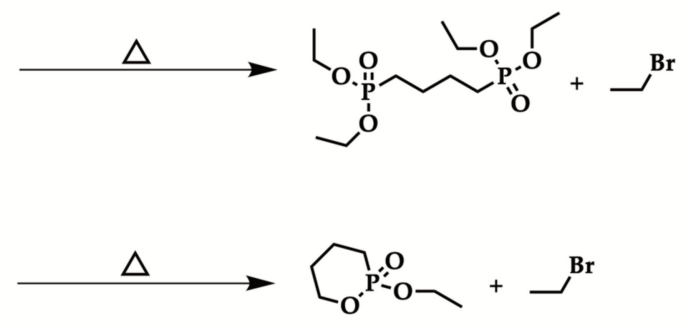

(d)

)

Scheme 3. (a): Arbuzov reaction for the synthesis of 3; (b-d) concurrent processes: diethyl ethylphosphonate generation (b), di-phosphonation (c) and cyclization (d).

To improve the experimental conditions, the same reaction was performed while distilling the generated bromoethane (Table 1, Entry 2); this was also useful to monitor the progress of the reaction. Product analysis pointed out that di-substitution reaction (Scheme 3c) and intramolecular cyclization of $\mathbf{3}$ (Scheme 3d) occurred, thus forming a stable six-membered heterocycle [44]. Additionally, in this case, only traces of the mono-substituted product were detected. Microwave irradiation was attempted [51,52], using equimolar reactants ratio, and an irradiation power of $150 \mathrm{~W}$ for $5 \mathrm{~min}$; however, the reaction lacked in selectivity (Table 1, Entry 3).

In order to avoid cyclization reaction to a stable 6-membered ring, 1,6-dibromohexane was used as the substrate, experimenting with the synthesis of diethyl 6-bromohexylphosphonate 
(1). Moreover, to promote mono-substitution reaction, triethyl phosphite was added dropwise in 30 minutes [44]. However, in such conditions, di-phosphonation process was again the predominant one, while 1 was isolated in very low yield (Table 1, Entry 4). It is noteworthy that slower triethyl phosphite addition (in about two hours) allowed to achieve 1, with high selectivity and satisfactory yield (40\%, Table 1 Entry 5$)$. Thus, such an optimized procedure was employed to synthesize diethyl 5-bromopentylphosphonate (2) (40\% yield, Table 1, Entry 6) and 3 (20\% yield, Table 1, Entry 7), in acceptable yields. Nevertheless, in the case of 3, it was necessary to further purify the product, since the intramolecular cyclization side-reaction occurred (Scheme 3d).

The obtained diethyl $\omega$-bromoalkylphosphonates (1-3) were then employed as reagents to synthesize new KuQuinone derivatives (4-6), bearing a diethyl phosphonate terminal group. KuQ synthesis was executed following the previously reported one-pot procedure [32], in which 2-hydroxy-1,4-naphthoquinone is reacted with an excess of an appropriate alkyl bromide, in the presence of a base and ferrocene $(\mathrm{FcH})$ in catalytic amount (Scheme 4). Overall, three KuQuinone phosphonate derivatives, differing in side-chain length, were synthesized with yields (7 to $11 \%$, Table 2 ) that compare well with that of other KuQuinone analogues [29,30,33].

2<smiles>O=C1C=C(O)C(=O)c2ccccc21</smiles><smiles>CCOP(=O)(OCC)OCC</smiles>

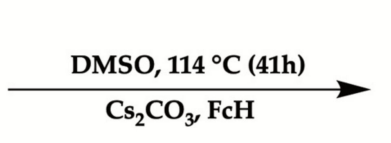
$\mathrm{Cs}_{2} \mathrm{CO}_{3}, \mathrm{FcH}$

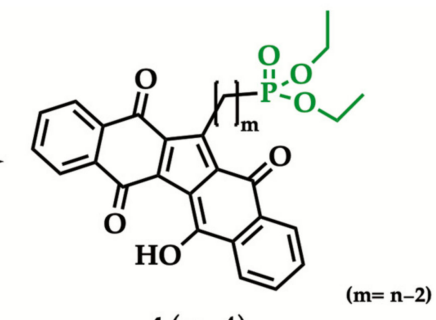

$4(\mathrm{~m}=4)$

$5(\mathrm{~m}=3)$

$6(\mathrm{~m}=2)$

Scheme 4. Synthesis of KuQuinone phosphonate esters 4-6.

Table 2. Synthesis of KuQuinone diethyl phosphonate derivatives. Reaction conditions: $5.75 \mathrm{mmol}$ of 2-hydroxy-1,4-naphthoquinone, $12 \mathrm{mmol}$ of bromoalkylphosphonate, $8 \mathrm{mmol}$ of $\mathrm{Cs}_{2} \mathrm{CO}_{3}, 0.33 \mathrm{mmol}$ of $\mathrm{FCH}$, in $22 \mathrm{~mL}$ of DMSO, at $114^{\circ} \mathrm{C}$, for $41 \mathrm{~h}$.

\begin{tabular}{ccc}
\hline Reagent & Product & Yield (\%) \\
\hline $\mathbf{1}$ & 4 & 11 \\
2 & 5 & 10 \\
3 & 6 & 7 \\
\hline
\end{tabular}

To achieve KuQuinone phosphonic acids, KuQ-phosphonate esters hydrolysis was performed [53]. Reaction with 48\% hydrobromic acid, at reflux, was first studied [54]. Despite the harsh conditions adopted, the phosphonic acid was not obtained. Acid hydrolysis was then performed with $0.5 \mathrm{M}$ of hydrochloric acid, under microwave irradiation, with no results, likely because of the poor KuQuinone solubility in water [55]. Additionally, hydrolysis with bromotrimethylsilane (TMSBr) [56-58] was not successful. At this point, considering a seminal work by Morita [59], KuQuinone phosphonate ester hydrolysis has been performed with TMSBr in the presence of NaI (Table 3). In fact, because of the higher nucleophilicity of the iodide compared to other halides, trimethylsilyl intermediate formation is favored. Therefore, the reaction was carried out, dissolving $0.1 \mathrm{mmol}$ of $\mathrm{KuQ}$ phosphonate ester in dry chloroform/acetonitrile (1:1), with a large excess of $\mathrm{NaI}$ and TMSBr (5 mmol), under $\mathrm{N}_{2}$ atmosphere, at $40{ }^{\circ} \mathrm{C}$. After $4 \mathrm{~h}$, the generated intermediate (trimethylsililphosphonate ester) was converted to the corresponding acid by methanolysis at room temperature (Scheme 5). The reaction was checked with TLC and interrupted when the ester band disappeared. In these conditions, almost quantitative conversions of KuQuinone phosphonate esters 4-6 to phosphonic acids 7-9 were achieved. 
Table 3. Hydrolysis of KuQuinone phosphonate esters. Conditions: $0.1 \mathrm{mmol}$ of diethyl phosphonate KuQuinone, $5 \mathrm{mmol}$ of $\mathrm{NaI}, 5 \mathrm{mmol}$ of bromotrimethylsilane, in $16 \mathrm{~mL}$ of dry $\mathrm{CH}_{3} \mathrm{CN}: \mathrm{CHCl}_{3}$ (1: 1), at $40^{\circ} \mathrm{C}, 4 \mathrm{~h}$, under $\mathrm{N}_{2}$ atmosphere. Then, silyl ester hydrolysis was performed with $30 \mathrm{~mL}$ of methanol.

\begin{tabular}{ccc}
\hline Reagent & Product & Yield (\%) \\
\hline 4 & 7 & 100 \\
5 & 8 & 95 \\
6 & 9 & 97 \\
\hline
\end{tabular}

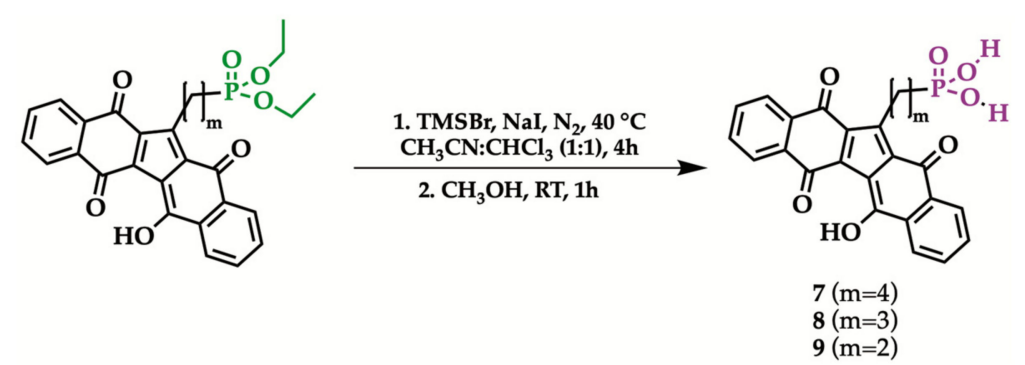

Scheme 5. Hydrolysis of KuQuinone phosphonate esters.

Note that KuQ phosphonate esters were highly soluble in all conventional organic solvents. Conversely, phosphonic acid derivatives were insoluble in apolar organic solvents and they showed only poor solubility in methanol and dimethyl sulfoxide. Solubility was significantly enhanced in water in the presence of a base, which allows phosphonic acid deprotonation and dissolution [60].

Therefore, KuQ phosphonic acid characterization was performed with NMR in DMSO$d_{6} .{ }^{1} \mathrm{H}$ NMR spectra were characterized by a large and intense peak at about $3.4 \mathrm{ppm}$, which is typical of organic phosphonic acids (Figures S13, S17 and S21), being attributable to the hydroxyl groups of PA moiety, as well as to water traces [61]. Such intense peak overlaps with some KuQ aliphatic signals in the ${ }^{1} \mathrm{H}$ NMR spectrum of the products, that are also broad and not well-resolved, likely because of the compound's low solubility in DMSO. Conversely, KuQuinones characteristic peaks were clearly observed in the aromatic region of the spectra. On the other hand, ${ }^{31} \mathrm{P}$ NMR analysis unambiguously confirmed the effectiveness of the hydrolysis [62]. In fact, by comparing the ${ }^{31} \mathrm{P}$ NMR spectra in DMSO- $d_{6}$ of the phosphonate esters with the corresponding phosphonic acids (Figure 1), a shift of about 5 ppm fields was observed, according to literature data [62].

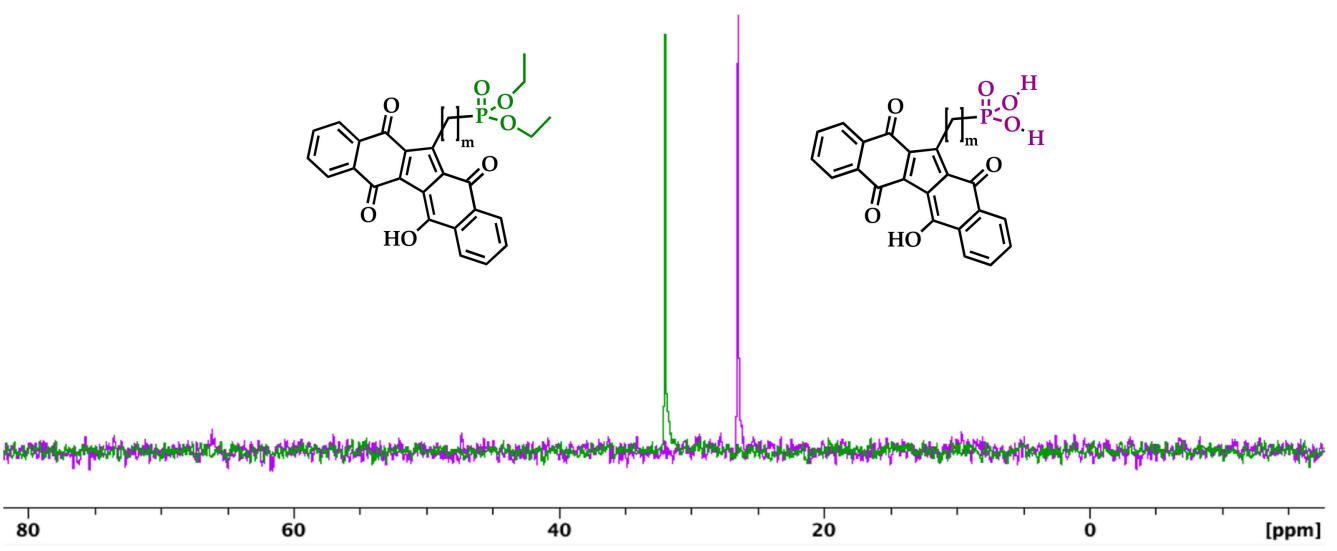

Figure 1. ${ }^{31} \mathrm{P}$ NMR spectra of 8 (purple) and 5 (green) in DMSO- $d_{6}$. 


\section{Conclusions}

In this paper, Arbuzov reaction for the synthesis of $\omega$-bromoalkylphosphonates has been optimized. In fact, the main drawback in published synthetic procedures of $\omega$ bromoalkylphosphonates was the large excess of the substrate, i.e., a $\alpha, \omega$-dibromoalkane, in order to prevent the di-substitution side process. Here, we report that slow dropwise addition of triethyl phosphite to 1 equivalent a $\alpha, \omega$-dibromoalkane leads to the desired product, with satisfactory yields. Importantly, reactions occur at $140{ }^{\circ} \mathrm{C}$, while distilling bromoethane, that is formed as the first byproduct. Note that reactions performed using 1,4-dibromobutane as the substrate lead to a high amount of the cyclization side-product, thus lowering yields.

The optimized reaction conditions allow to significantly reduce the amount of the substrate, consequently reducing $\alpha, \omega$-dibromoalkane waste. Moreover, substrate scope can be further extended to obtain a library of $\omega$-bromoalkylphosphonates.

The synthesized $\omega$-bromoalkylphosphonates have been experimented in the synthesis of KuQuinone diethyl phosphonate derivatives, following a previously reported procedure. Hence, novel KuQuinone phosphonate esters have been synthesized and their hydrolysis with TMSBr and NaI allowed to access new KuQuinone phosphonic acids, with almost quantitative yields.

The introduction of a phosphonate ester in KuQ side chain sensibly enhances the solubility of such compounds in organic solvents. More importantly, a phosphonic acid functionality is strategic to exploit KuQuinones in different applications, such as in photo(electro)chemical devices anchored on suitable metal oxide nanoparticles, as well as in photocatalysis and biomedical applications.

Supplementary Materials: The following are available online at https:/ /www.mdpi.com/article/10 .3390 / org2020010/s1, Figure S1: ${ }^{1} \mathrm{H}$ NMR spectrum of 1 in $\mathrm{CDCl}_{3}$; Figure S2: ${ }^{31} \mathrm{P}$ NMR spectrum of 1 in $\mathrm{CDCl}_{3}$; Figure S3: Mass spectrum of 1; Figure S4: ${ }^{1} \mathrm{H}$ NMR spectrum of 2 in $\mathrm{CDCl}_{3}$; Figure S5:

${ }^{31} \mathrm{P}$ NMR spectrum of 2 in $\mathrm{CDCl}_{3}$; Figure S6: Mass spectrum of 2; Figure S7: ${ }^{1} \mathrm{H}$ NMR spectrum of 3 in $\mathrm{CDCl}_{3}$; Figure S8: ${ }^{31} \mathrm{P} \mathrm{NMR}$ spectrum of 3 in $\mathrm{CDCl}_{3}$; Figure S9: Mass spectrum of 3; Figure S10: ${ }^{1} \mathrm{H}$ NMR spectrum of 4 in $\mathrm{CDCl}_{3}$; Figure $\mathrm{S11}$ : ${ }^{13} \mathrm{C}$ NMR spectrum of 4 in $\mathrm{CDCl}_{3}$; Figure $\mathrm{S12}^{31} \mathrm{P}$ NMR spectrum of 4 in $\mathrm{CDCl}_{3}$; Figure S13: HRMS spectrum of 4; Figure S14: UV-vis spectrum of 4; Figure S15: ATR-IR spectrum of 4; Figure S16: ${ }^{1} \mathrm{H}$ NMR spectrum of 7 in DMSO- $d_{6}$; Figure S17: ${ }^{31} \mathrm{P}$ NMR spectrum of 7 in DMSO- $d_{6}$; Figure S18: HRMS of 7; Figure S19: ATR-IR spectrum of 7; Figure S20: ${ }^{1} \mathrm{H}$ NMR spectrum of 5 in $\mathrm{CDCl}_{3}$; Figure S21: ${ }^{13} \mathrm{C} \mathrm{NMR} \mathrm{spectrum} \mathrm{of} 5$ in $\mathrm{CDCl}_{3}$; Figure S22: ${ }^{31} \mathrm{P}$ NMR spectrum of 5 in $\mathrm{CDCl}_{3}$; Figure S23: HRMS spectrum of 5; Figure S24: UV-vis spectrum of 5 in $\mathrm{CHCl}_{3}$; Figure S25: ATR-IR spectrum of 5; Figure S26: ${ }^{1} \mathrm{H}$ NMR spectrum of 8 in DMSO- $d_{6}$; Figure S27: ${ }^{31} \mathrm{P}$ NMR spectrum of 8 in DMSO- $d_{6}$; Figure S28: HRMS spectrum of 8; Figure S29: ATR-IR spectrum of 8; Figure S30: ${ }^{1} \mathrm{H}$ NMR spectrum of 6 in $\mathrm{CDCl}_{3}$; Figure S31: ${ }^{13} \mathrm{C}$ NMR spectrum of 6 in $\mathrm{CDCl}_{3}$; Figure S32: ${ }^{31} \mathrm{P} \mathrm{NMR}$ spectrum of 6 in $\mathrm{CDCl}_{3}$; Figure S33: HRMS spectrum of 6; Figure S34: UV-vis spectrum of 6 in $\mathrm{CHCl}_{3}$; Figure S35: ATR-IR spectrum of 6; Figure S36: ${ }^{1} \mathrm{H}$ NMR spectrum of 9 in DMSO- $d_{6}$; Figure S37: ${ }^{31} \mathrm{P}$ NMR spectrum of 9 in DMSO- $d_{6}$; Figure S38: HRMS spectrum of 9; Figure S39: ATR-IR spectrum of $\mathbf{9}$.

Author Contributions: Conceptualization, F.S. and P.G.; methodology, M.F. and P.G.; validation, M.F., F.S. and P.G.; formal analysis, M.F. and G.F.; investigation, M.F., F.S. and P.G.; resources, P.G.; data curation, M.F. and F.S.; writing—original draft preparation, M.F. and F.S.; writing-review and editing, F.S., P.G. and V.C.; supervision, P.G. and V.C.; project administration, F.S. and P.G.; funding acquisition, F.S. and P.G. All authors have read and agreed to the published version of the manuscript.

Funding: This research was funded by University of Rome Tor Vergata, grant HYPHOTOCAT project, "Beyond borders".

Data Availability Statement: The data presented in this study are available on request from the corresponding author.

Acknowledgments: YERUN Network is acknowledged for the opportunity to start this project. Claudia Mazzuca is gratefully acknowledged for ATR-IR measurements. 
Conflicts of Interest: The authors declare no conflict of interest.

\section{References}

1. Lyagin, I.; Efremenko, E. Enzymes, Reacting with Organophosphorus Compounds as Detoxifiers: Diversity and Functions. Int. J. Mol. Sci. 2021, 22, 1761. [CrossRef]

2. Wiemer, A.J.; Wiemer, D.F. Prodrugs of phosphonates and phosphates: Crossing the membrane barrier. Top. Curr. Chem. 2015, 360, 115-160. [CrossRef]

3. Tan, E.L.; Ooi, E.E.; Lin, C.Y.; Tan, H.C.; Ling, A.E.; Lim, B.; Stanton, L.W. Inhibition of SARS coronavirus infection in vitro with clinically approved antiviral drugs. Emerg. Infect. Dis. 2004, 10, 581-586. [CrossRef]

4. De Clercq, E. Clinical Potential of the Acyclic Nucleoside Phosphonates Cidofovir, Adefovir, and Tenofovir in Treatment of DNA Virus and Retrovirus Infections. E. Clin. Microbiol. Rev. 2003, 16, 569-596. [CrossRef] [PubMed]

5. Bray, W. Covid-19 Drug Design via Quantum Mechanical Principles Leads to a New Corona-SARS Anti- Viral Candidate 2-Phosphono-Benzoic-Acid. J. Theor. Comput. Sci. 2020. [CrossRef]

6. Verbrugghen, T.; Vandurm, P.; Pouyez, J.; Maes, L.; Wouters, J.; Van Calenbergh, S.J. Alpha-Heteroatom Derivatized Analogues of 3-(Acetylhydroxyamino)propyl Phosphonic Acid (FR900098) as Antimalarials. Med. Chem. 2013, 56, 376-380. [CrossRef] [PubMed]

7. Falagas, M.E.; Vouloumanou, E.K.; Samonis, G.; Vardakas, K.Z. Fosfomycin. Clin. Microbiol. Rev. 2016, 29, 321-347. [CrossRef]

8. Savjani, K.T.; Gajjar, A.K.; Savjani, J.K. Drug solubility: Importance and enhancement techniques. ISRN Pharm. 2012, 1-10. [CrossRef] [PubMed]

9. Deng, X.; Hu, J.Y.; Luo, J.; Liao, W.M.; He, J. Conductive Metal-Organic Frameworks: Mechanisms, Design Strategies and Recent Advances. Top. Curr. Chem. 2020, 378, 27. [CrossRef]

10. Hix, G.B.; Caignaert, V.; Rueff, J.M.; Le Pluart, L.; Warren, J.E.; Jaffrès, P.A. A Supramolecular Ladderlike Structure Formed by the Auto-Assembly of Benzene-1,3,5-triphosphonic Acid. Cryst. Growth Des. 2007, 7, 208-211. [CrossRef]

11. Sopkova-de Oliveira Santos, J.; Montouillout, V.; Fayon, F.; Fernandez, C.; Delain-Bioton, L.; Villemin, D.; Jaffrès, P.A. Assembly of benzene-1,3,5-tris(methylenephosphonic acid) and guanidinium salt: Single crystal-X-ray characterisation and ${ }^{31} \mathrm{P}$ solid state NMR investigations. New J. Chem. 2004, 28, 1244-1249. [CrossRef]

12. Jiménez-García, L.; Kaltbeitzel, A.; Enkelmann, V.; Gutmann, J.S.; Klapper, M.; Müllen, K. Organic Proton-Conducting Molecules as Solid-State Separator Materials for Fuel Cell Applications. Adv. Funct. Mater. 2011, 21, 2216-2224. [CrossRef]

13. Hotchkiss, P.J.; Jones, S.C.; Paniagua, S.A.; Sharma, A.; Kippelen, B.; Armstrong, N.R.; Marder, S.R. The Modification of Indium Tin Oxide with Phosphonic Acids: Mechanism of Binding, Tuning of Surface Properties, and Potential for Use in Organic Electronic Applications. Acc. Chem. Res. 2012, 45, 337-346. [CrossRef]

14. Queffélec, C.; Petit, M.; Janvier, P.; Knight, D.A.; Bujoli, B. Surface Modification Using Phosphonic Acids and Esters. Chem. Rev. 2012, 112, 3777-3807. [CrossRef]

15. Pujari, S.P.; Scheres, L.; Marcelis, A.T.M.; Zuilhof, H. Covalent Surface Modification of Oxide Surfaces. Angezw. Chem. Int. Ed. 2014, 53, 6322-6356. [CrossRef]

16. Boissezon, R.; Muller, J.; Beaugeard, V.; Monge, S.; Robin, J.J. Organophosphonates as anchoring agents onto metal oxide-based materials: Synthesis and applications. RSC Adv. 2014, 4, 35690-35707. [CrossRef]

17. Villemin, D.; Moreau, B.; Siméon, F.; Maheut, G.; Fernandez, C.; Montouillout, V.; Caignaert, V.; Jaffrès, P.A. A one step process for grafting organic pendants on alumina via the reaction of alumina and phosphonate under microwave irradiation. Chem. Commun. 2001, 2060-2061. [CrossRef]

18. Zeininger, L.; Portilla, L.; Halik, M.; Hirsch, A. Quantitative Determination and Comparison of the Surface Binding of Phosphonic Acid, Carboxylic Acid, and Catechol Ligands on $\mathrm{TiO}_{2}$ Nanoparticles. Chem. Eur. J. 2016, 22, 13506-13512. [CrossRef] [PubMed]

19. Lafond, V.; Gervais, C.; Maquet, J.; Prochnow, D.; Babonneau, F.; Mutin, P.H. ${ }^{17}$ O MAS NMR Study of the Bonding Mode of Phosphonate Coupling Molecules in a Titanium Oxo-Alkoxo-Phosphonate and in Titania-Based Hybrid Materials. Chem. Mater. 2003, 15, 4098-4103. [CrossRef]

20. Holland, G.P.; Sharma, R.; Agola, J.O.; Amin, S.; Solomon, V.C.; Singh, P.; Buttry, D.A.; Yarger, J.L. NMR Characterization of Phosphonic Acid Capped $\mathrm{SnO}_{2}$ Nanoparticles. Chem. Mater. 2007, 19, 2519-2526. [CrossRef]

21. Tudisco, C.; Oliveri, V.; Cantarella, M.; Vecchio, G.; Condorelli, G.G. Cyclodextrin Anchoring on Magnetic Fe $\mathrm{O}_{4} \mathrm{Nanoparticles}$ Modified with Phosphonic Linkers. Eur. J. Inorg. Chem. 2012, 32, 5323-5331. [CrossRef]

22. Zhang, L.; Cole, J.M. Anchoring Groups for Dye-Sensitized Solar Cells. ACS Appl. Mater. Interfaces 2015, 7, 3427-3455. [CrossRef]

23. Büttner, A.; Brauchli, S.Y.; Vogt, R.; Constable, E.C.; Housecroft, C.E. Combining phosphonic acid-functionalized anchoring ligands with asymmetric ancillary ligands in bis(diimine)copper(I) dyes for dye sensitized solar cells. RSC Adv. 2016, 6, 5205-5213. [CrossRef]

24. De Tovar, J.; Romero, N.; Denisov, S.A.; Bofill, R.; Gimbert-Surinach, C.; Ciuculescu-Pradines, D.; Drouet, S.; Llobet, A.; Lecante, P.; Colliere, V.; et al. Light-driven water oxidation using hybrid photosensitizer-decorated $\mathrm{Co}_{3} \mathrm{O}_{4}$ nanoparticles. Mat. Today Energy 2018, 9, 506-515. [CrossRef]

25. Xie, G.; Feng, D.; Ma, X. 9-Amino(9-deoxy)epi-cinchona alkaloid-tethered aluminium phosphonate architectures for heterogeneous cooperative catalysis: Asymmetric aldol and double-Michael cascade reaction. Mol. Cat. 2017, 434, 86-95. [CrossRef] 
26. Angeloni, M.; Piermatti, O.; Pizzo, F.; Vaccaro, L. Synthesis of Zirconium Phosphonate Supported L-Proline as an Effective Organocatalyst for Direct Asymmetric Aldol Addition. Eur. J. Org. Chem. 2014, 8, 1716-1726. [CrossRef]

27. Wan, J.; Ding, L.; Wu, T.; Ma, X.; Tang, Q. Facile one-pot fabrication of magnetic nanoparticles (MNPs)-supported organocatalysts using phosphonate as an anchor point through direct co-precipitation method. RSC Adv. 2014, 4, 38323-38333. [CrossRef]

28. Sabuzi, F.; Armuzza, V.; Conte, V.; Floris, B.; Venanzi, M.; Galloni, P.; Gatto, M. KuQuinones: A new class of quinoid compounds as photoactive species on ITO. J. Mater. Chem. C 2016, 4, 622-629. [CrossRef]

29. Bonomo, M.; Sabuzi, F.; Di Carlo, A.; Conte, V.; Dini, D.; Galloni, P. KuQuinones as sensitizers of NiO based p-type dye sensitized solar cells. New J. Chem. 2017, 41, 2769-2779. [CrossRef]

30. Volpato, G.A.; Marasi, M.; Gobbato, T.; Valentini, F.; Sabuzi, F.; Gagliardi, V.; Bonetto, A.; Marcomini, A.; Berardi, S.; Conte, V.; et al. Photoanodes for water oxidation with visible light based on a pentacyclic quinoid organic dye enabling proton-coupled electron transfer. Chem. Commun. 2020, 56, 2248-2251. [CrossRef] [PubMed]

31. Valentini, F.; Sabuzi, F.; Conte, V.; Nemykin, V.N.; Galloni, P. Unveiling KuQuinone redox species: An electrochemical and computational cross study. J. Org. Chem. 2021, 86, 5680-5689. [CrossRef]

32. Coletti, A.; Lentini, S.; Conte, V.; Floris, B.; Bortolini, O.; Sforza, F.; Grepioni, F.; Galloni, P. Unexpected One-Pot Synthesis of Highly Conjugated Pentacyclic Diquinoid Compounds. J. Org. Chem. 2012, 77, 6873-6879. [CrossRef]

33. Sabuzi, F.; Lentini, S.; Sforza, F.; Pezzola, S.; Fratelli, S.; Bortolini, O.; Floris, B.; Conte, V.; Galloni, P. KuQuinones Equilibria Assessment for Biomedical Applications. J. Org. Chem. 2017, 82, 10129-10138. [CrossRef] [PubMed]

34. Guerrero, G.; Alauzun, J.G.; Granier, M.; Laurencin, D.; Mutin, P.H. Phosphonate Coupling Molecules for the Control of Surface/Interface Properties and the Synthesis of Nanomaterials. Dalton Trans. 2013, 42, 12569-12585. [CrossRef] [PubMed]

35. Hagfeldt, A.; Boschloo, G.; Sun, L.; Kloo, L.; Pettersson, H. Dye-Sensitized Solar Cells. Chem. Rev. 2010, 110, 6595-6663. [CrossRef]

36. Gardner, T.J.; Frisbie, C.D.; Wrighton, M.S. Systems for Orthogonal Self-Assembly of Electroactive Monolayers on Au and ITO: An Approach to Molecular Electronics. J. Am. Chem. Soc. 1995, 117, 6927-6933. [CrossRef]

37. Lalatonne, Y.; Paris, C.; Serfaty, J.M.; Weinmann, P.; Lecouvey, M.; Motte, L. Bis-Phosphonates-Ultra Small Superparamagnetic Iron Oxide Nanoparticles: A Platform Towards Diagnosis and Therapy. Chem. Commun. 2008, 2553-2555. [CrossRef] [PubMed]

38. Péchy, P.; Rotzinger, F.P.; Nazeeruddin, M.K.; Kohle, O.; Zakeeruddin, S.M.; Humphry-Baker, R.; Grätzel, M. Preparation of Phosphonated Polypyridyl Ligands to Anchor Transition-Metal Complexes on Oxide Surfaces: Application for the Conversion of Light to Electricity with Nanocrystalline $\mathrm{TiO}_{2}$ Films. J. Chem. Soc. Chem. Commun. 1995, 65-66. [CrossRef]

39. Koh, S.E.; McDonald, K.D.; Holt, D.H.; Dulcey, C.S. Phenylphosphonic Acid Functionalization of Indium Tin Oxide: Surface Chemistry and Work functions. Langmuir 2006, 22, 6249-6255. [CrossRef]

40. Michaelis, A.; Kaehne, R. Ueber das Verhalten der Jodalkyle gegen die sogen. Phosphorigsäureester oder O-Phosphine. Ber. Dtsch. Chem. Ges. 1898, 31, 1048-1055. [CrossRef]

41. Bhattacharya, A.K.; Thyagarajan, G. The Michaelis-Arbuzov Rearrangement. Chem. Rev. 1981, 81, 415. [CrossRef]

42. Catel, Y.; Degrange, M.; Le Pluart, L.; Madec, P.J.; Pham, T.N.; Picton, L. Synthesis, Photopolymerization and Adhesive Properties of New Hydrolytically Stable Phosphonic Acids for Dental Applications. J. Polym. Sci. A Polym. Chem. 2008, 46, 7074-7090. [CrossRef]

43. Ohashi, K.; Kosai, S.; Arizuka, M.; Watanabe, T.; Yamagiwa, Y.; Kamikawa, T. Syntheses of D-erythro-1-deoxydihydroceramide1-sulfonic acid and phosphonosphingoglycolipid found in marine organisms via a common precursor. Tetrahedron 1989, 45, 2557-2570. [CrossRef]

44. Ragulin, V.V. $\omega$-Haloalkylphosphoryl Compounds: Synthesis and Properties. Russian, J. Gen. Chem. 2012, 82, 1928-1937. [CrossRef]

45. Hewitt, D.G.; Newland, G.L. Organophosphorus compounds. P-arylated perhydro-1,2-azaphosphorines. Aust. J. Chem 1977, 30, 579-587. [CrossRef]

46. Matoba, K.; Yonemoto, H.; Fukui, M.; Yamazaki, T. Structural modification of bioactive compounds. Syntheses of aminophosphonic acids. Chem. Pharm. Bull. 1984, 32, 3918-3925. [CrossRef]

47. Groenewold, G.S.; Scott, J.R.; Lee, E.D.; Lammert, S.A. Rapid analysis of organophosphonate compounds recovered from vinyl floor tile using vacuum extraction coupled with a fast-duty cycle GC/MS. Anal. Methods 2013, 5, 2227-2236. [CrossRef]

48. McLafferty, F.W. Mass spectrometric analysis. Molecular rearrangements. Anal. Chem. 1959, 31, 82-87. [CrossRef]

49. Li, F.; Shishkin, E.; Mastro, M.A.; Hite, J.K.; Eddy, C.R.; Edgar, J.H.; Ito, T. Photopolymerization of Self-Assembled Monolayers of Diacetylenic Alkylphosphonic Acids on Group-III Nitride Substrates. Langmuir 2010, 26, 10725-10730. [CrossRef]

50. Subedi, Y.P.; Alfindee, M.N.; Shrestha, J.P.; Becker, G.; Grilley, M.; Takemoto, J.Y.; Chang, C.W.T. Synthesis and biological activity investigation of azole and quinone hybridized phosphonates. Bioorg. Med. Chem. Lett. 2018, 28, 3034-3037. [CrossRef]

51. Villemin, D.; Simeon, F.; Decreus, H.; Jaffres, P.A. Rapid and efficient arbuzov reaction under microwave irradiation. Phosphorus Sulfur Silicon Relat. Elem. 1998, 133, 209-213. [CrossRef]

52. Cherevatskaya, M.; Neumann, M.; Füldner, S.; Harlander, C.; Kümmel, S.; Dankesreiter, S.; Pfitzner, A.; Zeitler, K.; König, B. Visible-Light-Promoted Stereoselective Alkylation by Combining Heterogeneous Photocatalysis with Organocatalysis. Angew. Chem. Int. Ed. 2012, 51, 4062-4066. [CrossRef]

53. Sevrain, C.M.; Berchel, M.; Couthon, H.; Jaffrès, P.A. Phosphonic acid: Preparation and applications. Beilstein J. Org. Chem. 2017, 13, 2186-2213. [CrossRef] [PubMed] 
54. Ikenberry, M.; Peña, L.; Wei, D.; Wang, H.; Bossmann, S.H.; Wilke, T.; Wang, D.; Komreddy, V.R.; Rillema, D.P.; Hohn, K.L. Acid monolayer functionalized iron oxide nanoparticles as catalysts for carbohydrate hydrolysis. Green Chem. 2014, 16, 836-843. [CrossRef]

55. Jansa, P.; Baszczyňski, O.; Procházková, E.; Dračinský, M.; Janeba, Z. Microwave-assisted hydrolysis of phosphonate diesters: An efficient protocol for the preparation of phosphonic acids. Green Chem. 2012, 14, 2282-2288. [CrossRef]

56. Besse, V.; Le Pluart, L.; Cook, W.D.; Pham, T.N.; Madec, P.J. Synthesis and polymerization kinetics of acrylamide phosphonic acids and esters as new dentine adhesives. J. Polym. Sci. A Polym. Chem. 2013, 51, 149-157. [CrossRef]

57. Norris, M.R.; Concepcion, J.J.; Glasson, C.R.K.; Fang, Z.; Lapides, A.M.; Ashford, D.L.; Templeton, J.L.; Meyer, T.J. Synthesis of Phosphonic Acid Derivatized Bipyridine Ligands and Their Ruthenium Complexes. Inorg. Chem. 2013, 52, 12492-12501. [CrossRef]

58. Zhou, Y.; Ayad, S.; Ruchlin, C.; Posey, V.; Hill, S.P.; Wu, Q.; Hanson, K. Examining the Role of Acceptor Molecule Structure in Self-Assembled Bilayers: Surface Loading, Stability, Energy Transfer, and Upconverted Emission. Phys. Chem. Chem. Phys. 2018, 20, 20513-20524. [CrossRef]

59. Morita, T.; Okamoto, Y.; Sakurai, H. A convenient dealkylation of dialkyl phosphonates by chlorotrimethylsilane in the presence of sodium iodide. Tetrahedron Lett. 1978, 28, 2523-2526. [CrossRef]

60. Franz, R.G. Comparisons of pKa and $\log \mathrm{P}$ values of some carboxylic and phosphonic acids: Synthesis and measurement. AAPS Pharm. Sci. 2001, 3, 1-13. [CrossRef] [PubMed]

61. Papadimitriou, K.D.; Andreopoulou, A.K.; Kallitsis, J.K. Phosphonated fully aromatic polyethers for PEMFCs applications. J. Polym. Sci. A Polym. Chem. 2010, 48, 2817-2827. [CrossRef]

62. Kahraman, G.; Wang, D.Y.; Von Irmer, J.; Gallei, M.; Hey-Hawkins, E.; Eren, T. Synthesis and Characterization of Phosphorusand Carborane-Containing Polyoxanorbornene Block Copolymers. Polymers 2019, 11, 613-629. [CrossRef] [PubMed] 